\title{
Constructing the Hashemite Self-Identity in King Abdullah II's Discourse
}

\author{
Ahmad El-Sharif \\ Department of English Language and Literature, Al-alBayt University \\ P.O. Box 130200, Mafraq, Jordan \\ Tel: 962-262-970-000 Ext. 2245 E-mail: a.el-sharif@aabu.edu.jo
}

Received: Nov. 15, 2013 Accepted: February 18, 2014 Published: February 22, 2014

doi:10.5296/ijl.v6i1.5170 URL: http://dx.doi.org/10.5296/ijl.v6i1.5170

\begin{abstract}
The aim of this article is to show how King Abdullah II of Jordan represents the layers of the Hashemites' self-identity in his discourse. Within the framework of Critical Discourse Analysis, I explore the lexical and thematic choice by which King Abdullah II distinguishes himself, the Hashemite rulers, and Jordanians within the rhetoric of the exceptionality of the 'Hashemite Jordan' model. The article illustrates also how the discourse of the 'dominant' Hashemite ruling-class works on manufacturing the 'dominated' Jordanians' consensus about Hashemites' dominance and legitimacy through a set of three socio-cultural representations: the of historical legacy and religious affiliation, modernity and originality, and the of vanguard of reform.
\end{abstract}

Keywords: Self-identity (Note 1), Political discourse, Critical discourse analysis, Hashemites, Jordan 


\section{Introduction}

The subject of how members of groups conceptualise themselves and their activities and how they identify themselves triggers much discussion in linguistic research. It is argued that our conceptions of the self revolve around stereotypes and how individuals act in accordance with their surrounding cultural systems (De Cillia et al., 1999: 150). Taking the example of dominant ruling-classes, one might wonder how positive socio-cultural stereotypes assigned to these classes make potent tools of manipulation to legitimate activities and domination over the dominated groups. Dominant ruling-classes perpetuate their self-representation through propaganda in public discourse to maintain the consensus of the dominated group. Accordingly, understanding how members of ruling-classes conceptualise themselves and their activities helps understanding the many embedded relationships and structures of society which help materialising this consensus. Herein, the self-identity of the dominant ruling-class works on constructing and structuring a discourse with its rhetoric is to align themselves to the standards of legitimacy as established by the norms and conventions of society.

The process of identity construction is basically a face-to-face process whereby interactions are framed within social institutions and enacted by various interlocutors (Goffman, 1959). Then, the different aspects, and layers, of one's, or a group's, self-identity become socially and culturally situated through interaction with others. In their positioning theory, Davies and Harré argue that:

'Human beings are characterized both by continuous personal identity and by discontinuous personal diversity. It is one and the same person who is variously positioned in a conversation. Yet as variously positioned we may want to say that that very same person experiences and displays that aspect of self that is involved in the continuity of a multiplicity of selves' (Davies and Harré, 1990: 46-47).

Thus, 'self-identity' is understood in terms of the ongoing process of verbal self-representation of someone's positions and roles within the socio-political structure of society. In similar analogy, ruling-classes make an example of well-defined social groups within society, and their self-presentations are the reaction to the expectations of their subjects. This is why they likely to present multiple aspects, or layers, of their self-identity to their subjects. For instance, as the self-identity of some ruling-classes is built on the emphasis on what history positively says about it, history makes one of these layers. In most society, this layer is mostly brought to light by the continuous calling of the 'collective memory' of society; which is regarded as 'the selective recollection of past events which are thought to be important for the members of a specific community' (Halbwachs, Maurice; cited in De Cillia, 1999: 154). And the practice of calling these 'collective memories' back makes part of the discourses of ruling-classes by which they create sets of common representations that characterise its self-identity and the socio-political relationship it maps with the state it rules. The emergent matrix of socio-political representations and relationships and the political system works on the re-construction of individual self-identities to make a national one. This identity, as Wodak et al. accentuate, is 'constructed and conveyed in discourse'...as the 
concept nation is realised as 'a mental construct, an imaginary complex of ideas ... this image is real to the extent that one is convinced of it, believes in it and identifies with it emotionally' (Wodak et al., 1999: 22).

Starting from the previous brief line of reasoning, this article embarks upon the case of the construction of self-identity of the Hashemite ruling-class in Jordan as presented in their discourse(s). I will mainly focus on illustrating the linguistic strategy of lexical choice and wordings employed by a member of the Hashemite ruling class to construct and reflect their in-group self-identity. Critical Discourse Analysis (Fairclough, 1995) is used here as a theoretical linguistic framework to reveal the unspoken arguments and meanings about the Hashemites' self-identity in a discourse produced by a Hashemite. This can be mostly attained by looking into how discourse practices convey - through forms and meanings - the logic by which the Hashemite dominant groups marginalize the other non-dominant ones; and revealing the underlying ideological arguments and beliefs that justify the values, beliefs, and ideologies of the Hashemite dominant group according to the different social orders of the Jordanian and Arabic society and culture (See Pennycook, 2001: 85-94).

\section{Self-Identity Construction and Critical Analysis of Discourse}

Studying the discourse of ruling classes reveals the many social relations which shape the ideological beliefs by which the dominants justify their dominance over the dominated. This discourse is perceived a product of the social processes within the given social context and it is seen as 'shaped by relations of power and ideologies' (Fairclough, 1992: 12). Additionally, this discourse makes a social world itself where social practices are understood via their relationships with the verbal strategies of this dominant group; such as strategies to assemble power asymmetries, strategies of inclusion and exclusion, and strategies to dismantle the other competing groups. The result involves the categorisation of people within a social, or an ideological, hierarchy and evaluating people, or activities, by ascribing them positive or negative values. By privileges of power and manipulation, dominant ruling-classes define these categories as membership devices, activities, aims and goals, norms and values, relations to other groups and resources or 'capital' (See van Dijk, 2003: 215) in order to define their own unique self-identity. And this is mainly attained by producing a discourse connected to the social, cultural, political, and historical information of society. This discourse would be loaded with ideological assumptions and social relationships of power and domination as structured within society (See van Dijk, 1993). Them one can deduce how these relationships work on constructing the self-identity of a ruling class in its own discourse.

Our case study here is the Hashemite ruling-class's self-identity as constructed and negotiated in the discourse of one of its prominent members. The argument and discussion of this article focus on identifying how the Hashemite ruling-class in Jordan makes its self-identity through their language rather than questioning what identity it has (See Bamberg et al., 2011: 178. This is achieved by revealing the most frequent selection of language patterns and use to mark the 'acts of identity in which people reveal both their personal identity and their search for social roles' (LePage and Tabouret-Keller, 1985: 14). It is expected that members of the 
Hashemite ruling-class in Jordan are constrained in their language selection on Arab, Islamic, and Jordanian societal norms and traditions. These norms and traditions make the Hashemites, within a Foucauldian approach, engaged in discursive communal practices which construct and form their speeches and their worlds (Foucault, 1972). This practice is mostly perceived through their choice of language patterns that justify their dominance over the dominated group(s) by underlining, for example, their self-representation and the deeply-rooted and inherited beliefs that there dominated group(s) maintain in their 'collective memory' (Maurice Halbwachs's notion; cited in De Cillia, 1999: 154) imposed onto the dominated group through social practices. This 'collective memory' retrieves the distinctive positive qualities and representations of the ruling-class self-identity preserved in the societal and cultural 'repertoires' (in the Foucauldian sense) and which 'can arguably be viewed as categories or domains' (Bamberg et al., 2011: 180) which could be revealed through the critical analysis of discourse.

Critical Discourse Analysis (CDA) regards the self-identities of dominant groups discursively established by aspects of the political and ideological contexts in which the discourse made (Fairclough, 1989). It is also distinguished by its capability to control much of the daily institutional or organizational activities of society (Geison, 1983). Thus, to construct an identity, van Dijk sees that ideological discourse is semantically oriented towards local meanings and implications which characterise the description of self-identity (van Dijk, unknown: 147). He elaborates that constructing and establishing one's own (or a group's own) self-identity involves describing (all capitalisations are original):

...[w]ho are We, where do We come from, what are Our properties, what is Our history, how are We different from Others, what are We proud of; but also: boundary statements with respect to Others: Who will be admitted, what are the criteria of admission, who may immigrate, etc. (ibid.).

As self-identity is generally positive, dominant groups distinguish the different labels and stereotypes of 'self-identity descriptions' to define the members of their group. These labels and stereotypes are self-recognised or known by the others because of their many permanent, inherent or attributed characteristics, mainly in our case, origin, ethnicity, religion, and language (ibid.). In addition, van Dijk sees also that a group's self identity is established by 'activity-descriptions' which define the one's own (or the group's own) self-identity by what he/she (or they) do. This can be defined by the group highlighting 'What are Our tasks? What do We do? What is expected of Us? What are Our social roles, etc.?'. What is more, van Dijk elaborates that that a group's self identity is established by 'position and relation descriptions' in which '[g]roups define their identity, activities and goals largely also in relation to other groups.' (ibid: 148).

As one can infer from the exposition above, CDA emphasises how the many discursive constructions between the actors and their realities and actions can map expounding relationships to reflect a group's self-identity and the society where they emerge. The self-identity of dominant groups is recognised by highlighting the already existing societal and cultural 'repertoires' of the dominant group. These repertoires may include membership 
devices, aims, and goals, position, power and resources, deeds and achievement, norms and values, and relations to other groups. I hereby argue here that the Hashemite ruling-class in Jordan exhibits their self-identity tacitly or explicitly by attending to such categories in their 'collective memory', thought, and discourse.

\section{On the Hashemites}

The Hashemite ruling-class is regarded as one of the most distinguished ruling families in the history of the Arabs of the Middle East. Its fame is attributed to the claim of a direct lineage to the Arab tribe of Banu Hashim to which the Prophet Muhammad belongs. The Hashemites descendants of the Arab chieftain Quraysh, that is a descendant of the Prophet Ismail, himself the son of the Prophet Ibrahim (Abraham).

Historical accounts establish that Quraysh first came to the holy city of Mecca during the second century CE; however, they could not take rule of the city until Qusayy bin Kilab ascended to the leadership of Mecca in the year $480 \mathrm{CE}$. This latter's grandson, 'Hashim' was actually the great-grandfather of the Prophet Muhammad, and after his name the Banu Hashim tribe was renowned. Since then, several Hashemites rulers have ruled over the Hijaz (nowadays Saudi Arabia) region of Arabia between 967 and 1201 CE. Those Hashemite rulers acclaimed their direct lineage to the Prophet Muhammad through his daughter Fatima and her husband Ali bin Abi Talib, who was also a Hashemite himself, the Prophet's cousin, and later the fourth caliph of Islam. History tells that the Hashemites did not maintain power after the Caliph Ali bin Abi Talib, However, and in the past few centuries of the Islamic calendar, many Hashemite rulers had ruled in unbroken succession under the sovereignty of the Ottoman Sultan (Teitelbaum, 1998: 104). And after the collapse of the Ottoman Empire in 1916, many members of the Hashemite dynasty seized power in few Arab local governments in Syria, Iraq, and Jordan. Only in Jordan, the Hashemite family has survived the collapse of monarchies and the rise of revolutionary regimes in the forties and the fifties of the last century. For some historical accounts, when the Hashemites arrived to Transjordan (Jordan's name before independence), the land involved a large degree of social and ethnic diversity of native Bedouin tribes, Palestinians, Syrians, and even Circassians, Turks, and Armenians; a diversity that have challenged establishing a unified Jordanian identity and in many occasions (See Massad, 2001: 240; Salibi, 2006: 104).

Since their arrival to Jordan in the twenties of the last century, the Hashemite constructed the minority dominant group. Initially, the Hashemites tried to merge into the identity of the dominated Trans-Jordanian hosts in order to denounce two allegations: that their legitimacy is imposed upon Trans-Jordanians by the Western (British) backup (Lucas, 2008: 283); and that their identity and historical pseudo-affiliation is mostly to their homeland (the Hijaz). Successive Hashemite rulers denounced these allegations implicitly and explicitly, and they emphasised the great mutual social code between them and Jordanians is it has been truly reflected in the course of cohabitation, common well-good, shared destination.

\section{Methods}

In this article, I adopt a critical approach to discourse analysis that addresses the issue of 
power differences, dominance, and ideologies (Fairclough, 1995) within the Jordanian society. This is attained by working on finding the answers for how the (dominant) Hashemite group control discourse?; how does such discourse control the mind and action of the (dominated) Jordanian group?; and what are the social consequences of such a relationship between the dominant and the dominated groups? (See van Dijk, 2001: 355). The adopted critical approach tackles the description of meanings derived of the text in hand (textual analysis) and the discursive production and interpretation of the text (discourse practice) with the aim is to reveal the embedded broader social realities reflected in the text or structured by it (socio-cultural practice) (Fairclough, 1992: 4).

The target of my critical analysis then is the Hashemite self-identity as represented in the discourses of a member of this ruling-class on the basis of the Jordanian historical, social, and political context. Herein, the discourse selected is that of the current Jordanian Hashemite ruler: King Abdullah II.

My choice for this particular discourse is motivated by the assumption that the discourse of the Hashemite rulers of Jordan is constructed from a chain of shared and deeply-rooted ideas, beliefs and ideologies which have been inherited to the successive monarchs; father to son. Since its establishment, Jordan has known only four Hashemite monarchs: Prince (later King) Abdullah I bin AlHussein, King Talal bin Abdullah, King Hussein bin Talal, and King Abdullah II bin Hussein. Thus, it is reasonable to recognise that the discourse of King Abdullah II (KAII) encompasses the accumulated personal views of the Hashemite rulers in regard of their self-identity.

The data to be analysed consists of a collection of 311 texts involving all KAII's speeches, and letters since he ascended onto the throne in February 1999 until 25 December 2012. These texts are available in their original Arabic or English versions on KAII's official website (www.kingabdullah.jo). The content of these texts varies from speeches which have been addressed by the King in many local and international ceremonies and events and letters addressed to the newly designated prime ministers, officers, or the citizens in many occasions. All these texts were compiled and stored in a corpus of about 313,000 words in machine-readable form.

The contextual analysis involves the identification of all instances in which the Hashemites self-identity has been mentioned or indicated through wordings and expressions in the corpus. This was first attained by the automatic search for the lexical entries 'Hashem' (the root of the word 'Hashemite' in Arabic) or 'we the Hashemite' in Arabic using a qualitative research engine (NVivo 10) ${ }^{1}$. This involves highlighting (coding by NVivo 10) all lexical entries (nouns, adjectives, and verbs) which ascribe distinctive qualities to the Hashemites: their properties, attributes, and deeds. Then, the identified lexical entries were coded (again using NVivo 10) according to the 'repertoires' (in the Foucauldian sense); such as membership devices, aims, and goals, position, power and resources, deeds and activities, norms and

\footnotetext{
${ }^{1}$ NVivo is a qualitative data analysis computer software package that is designed for qualitative researchers working with very rich text-based and/or multimedia information. NVivo 10 helps users organize and analyze non-numerical or unstructured data by allowing users to classify, sort and arrange information; examine relationships in the data; and combine analysis with linking, shaping, searching and modelling.
} 


\section{MlMacrothink}

International Journal of Linguistics ISSN 1948-5425 2014, Vol. 6, No. 1

values, and relations to other groups. Finally, discussion of a representative selection of the most salient (and frequent) lexical entries, wordings, and expressions in relation to these 'repertoires' was introduced following the existing and established historical, societal, cultural, and political characteristics of the Hashemite ruling-class in Jordan.

\section{Findings and Illustrations}

It is found that KAII was relatively modest in exhibiting his, and the Hashemites', self-identity tacitly or explicitly in his discourse. In a large corpus of more than $300 \mathrm{k}$ words, the Hashemite King referred to the Hashemites' and their identity only 92 times. However, in all these instances, KAII remarkably represents the Hashemites through a rich variation of lexical entries that resulted a several patterns of wording and expressions which construct the in-group exceptional 'repertoires' of the Hashemites' self-identity; especially those relied on calling for the sense of social 'collective memory as to be shown below through a representative sample of these wordings and expressions (table 1):

Table 1. A sample of KAII's wording in constructing the different meanings and implications of the Hashemites' self identity in his discourse.

\begin{tabular}{|c|c|}
\hline Constructing self-identity & Lexical Entries \\
\hline \multicolumn{2}{|l|}{ Description of self-identity } \\
\hline - Who are We? & A Hashemite by birth / \\
\hline $\begin{array}{l}\text { - Where do We come } \\
\text { from? }\end{array}$ & descendant of the Prophet Mohammed \\
\hline $\begin{array}{l}\text { - What are Our } \\
\text { properties? }\end{array}$ & $\begin{array}{l}\text { conscious of its humanitarian / with a vision of } \\
\text { social and political reform / good governance in } \\
\text { state administration / filled with respect and } \\
\text { appreciation }\end{array}$ \\
\hline - What is Our history? & $\begin{array}{l}\text { The Prophet Muhammad / the Great Arab Revolt / } \\
\text { scarified our lives / offered many martyrs }\end{array}$ \\
\hline $\begin{array}{l}\text { - How are We different } \\
\text { from Others? }\end{array}$ & $\begin{array}{l}\text { selfless leader / modern democratic / derives its } \\
\text { solid roots from the Islamic religion, culture and way } \\
\text { of life / vanguard of constitutional reform / with a } \\
\text { Hashemite conscience and passion / the Hashemite } \\
\text { approach / offered many martyrs }\end{array}$ \\
\hline - What are We proud of? & $\begin{array}{l}\text { highborn ancestry / descending from the Hashemite } \\
\text { House / the Islamic Arab Hashemite heritage / Arab }\end{array}$ \\
\hline \multicolumn{2}{|l|}{ Activity-descriptions } \\
\hline - What are Our tasks? & $\begin{array}{l}\text { committed to highlight the image of faith and } \\
\text { practices of Islam / custodianship / bank on our } \\
\text { genuine, ingrained Hashemite role / noble message / } \\
\text { responsibility / historic role / duty / sacrifice / in the } \\
\text { service of this nation }\end{array}$ \\
\hline
\end{tabular}




\section{Mll Macrothink}

International Journal of Linguistics ISSN 1948-5425 2014, Vol. 6, No. 1

\begin{tabular}{|c|c|}
\hline do We do? & $\begin{array}{l}\text { advocates progress, prosperity and peace / promote } \\
\text { Jordan as a civilised model for tolerance, freedom of } \\
\text { thought, creativity and excellence / produce } \\
\text { outcomes that enhance the distinguished } \\
\text { performance of our political system / supporting } \\
\text { state institutions }\end{array}$ \\
\hline - What is expected of Us? & $\begin{array}{l}\text { A Hashemite by deeds / preserving Jerusalem's } \\
\text { Muslim and Christian holy sites / sacrificed / the } \\
\text { Hashemite umbrella of this country / }\end{array}$ \\
\hline $\begin{array}{l}\text { - What are Our social } \\
\text { roles? }\end{array}$ & $\begin{array}{l}\text { keep our doors wide open / [brought] justice, } \\
\text { freedom and respect of human rights / [brought] } \\
\text { values of the French Revolution / [brought] great } \\
\text { mutual admiration }\end{array}$ \\
\hline \multicolumn{2}{|l|}{$\begin{array}{lll}\begin{array}{l}\text { Position } \\
\text { descriptions }\end{array} & \text { and } & \text { relation } \\
\end{array}$} \\
\hline $\begin{array}{l}\text { - What is Our relationship } \\
\text { as dominant group with } \\
\text { the dominated Jordanian } \\
\text { group? }\end{array}$ & $\begin{array}{l}\text { my people / one of you / to serve you / fulfil your } \\
\text { noble aspirations / with its Hashemite mandate, is } \\
\text { Jordan the pioneer, Jordan the model and the } \\
\text { example to be followed / Jordan is a modern } \\
\text { democratic country,[...] that it is proud of belonging } \\
\text { to [....] highborn Hashemite ancestry / [Jordan } \\
\text { became] the pride of its men andwomen / brothers in } \\
\text { the service of our beloved country and our one } \\
\text { Jordanian family /Arab Hashemite haven }\end{array}$ \\
\hline
\end{tabular}

The 'repertoires' mentioned above describe aspects of the Hashemite in-group membership under the assumption that they are used by members of the Hashemites social group (See Farr and Moscovici, 1984). These repertoires make socio-cultural representations for these Hashemites' self identity as manifested in KAII's discourse, and they reflect a schematic organization that consists of fixed categories (van Dijk, unknown date: 139) similar to that which Jordanians (the dominated group) also assign to the Hashemites (the dominant group). Accordingly, one can that the Hashemite self-identity is represented in KAII's discourse through a set of repertoires which construct three key socio-cultural representation: historical legacy and religious affiliation, modernity and originality, and the vanguards of reform.

\subsection{Historical Legacy and Religious Affiliation}

This socio-cultural representation stands for KAII's endeavour in reflecting a self-identity description that verbally defines what are the Hashemite, who are They, where do They come from, what are Their properties, what is Their history, how are They different from Others (van Dijk, unknown: 147). Here, emphasising the Hashemites' legacy involves the constant calling of instantiations that involve the topicalization and thematization of eminent historical incidents to call for the 'collective memory' of Jordanian society about the Hashemites' and their role in the course of Arabic history and Islamic history. 
When it comes to the basic definition of 'who are We?', the Hashemites bride themselves with the fact that they are historically renowned by their lineage to Banu Hashem, the Arab tribe of the Prophet Muhammad (Lawrence, 1999: 48). For centuries, the Hashemite dynasty has governed the holy lands of Islam of Mecca and Medina (aka Hijaz) before King Abdul-Aziz Bin Saud's (the founder of the Saudi ruling dynasty) success in distancing them from those lands in 1924 (Chevallier, 2003: 27). An aspect of their most recent legacy is notably observed at the beginning of the $20^{\text {th }}$ century by Arab nationalists for the Hashemites' undeniable role in the Great Arab Revolt against the Turkish presence in the Arab region (Abu Rish, 2011). This achievement has maintained the Hashemites' image as a 'historical and religious symbol' of Arab nationalism in its entirety (Layne, 1994; Frisch, 2002).

Hashemite kings constantly link their rule to their historical legacy as descendants of the Prophet. This lineage has been repeatedly represented as a source of inspiration and guidance for the Hashemites in their rule and it allowed the Hashemites to affiliate their rule to Islam and faith. This can be perceived in KAII's discourse when he says:

1. ...., that it [Jordan] is proud of belonging to this nation and of its highborn Hashemite ancestry, that it is committed to highlight this bright and truthful image of the faith and practices of Islam,... (Speech from the Throne, Opening the First Ordinary Session of the $14^{\text {th }}$ Parliament, 01-Dec-03)

By referring to the Hashemites' in-group identity through appealing what have been historically known about them, KAII accentuates that what makes a Hashemite is first determined by the historical facts known about their 'high-born Hashemite ancestry' and their lineage to the Prophet Muhammad and which 'distinguishes' them from other Arab ruling families. The Hashemites' affiliation to the Prophet Muhammad and Islam as represented by KAII reflects another aspect of the Hashemites' self-identity description. Describing what is a Hashemite involves describing the properties of the Hashemites, their history, how are they different from others in their service to Islam in order to legitimise their governance as Muslim rulers.

As the Hashemites constantly regard their governance is based on the norms and values which their lineage to the Prophet entail, part of this governance involves legal procedures by which the Hashemites exercise their historical role as the heirs of their great grand-father's heritage as a Prophet and Custodian of Faith. An established materialisation of such legal role is the Hashemites' historical custodianships of the holy sites in the Holy Lands; especially, Al-Aqsa Holy Mosque in Jerusalem. King Abdullah II says:

2. The Al-Aqsa Mosque and Compound - Al-Haram Al-Sharif of East Jerusalem - is under Hashemite custodianship, a special role recognised by the 1994 Jordan-Israel peace treaty, ... (Speech Before the $67^{\text {th }}$ Plenary Session of the United Nations General Assembly, 25-Sep-12). 
3. The government is also expected to carry on Jordan's historical role in preserving Jerusalem's Muslim and Christian holy sites under Hashemite custodianship, ... (Letter to the already designated Prime Minister Mr. Abdullah Ensour, 10-Oct-12)

For centuries, maintaining Al-Aqsa Mosque has been the sacred duty that honours the Muslim ruler entrusted with, and after the Great Arab Revolt in 1916, the Hashemite rulers of Jordan took custody over the holy places in Palestine; involving Al-Aqsa. The lexical choice in the examples above accentuates the identity-description of the Hashemites in terms of their 'historical role' as the 'custodians' of the Islamic (and Christian) holy sites in Jerusalem. In this choice, KAII defines the Hashemites according to what they achieve to nation and faith. The socio-cultural representation of 'custodianship' refers to the 'repertoire by which the Hashemites are represented in KAII's discourse as the God's 'entrusted ones'. This repertoire makes one of the many resources of legitimacy for the Hashemites and their self-identity as 'custodians' to the sacred interests of all Muslims and Christians. This sacred task allows the Hashemites to proclaim their role as the 'unifiers' of major sects of faith around the world.

In another respect, the Hashemites' historical legacy and religious affiliation is addressed by KAII through his frequent appeal to the theme of 'sacrifice' in his discourse:

4. In spite of all these sacrifices, Jordan and the Jordanians, and Hashemite Kings, were unfairly accused; their role was doubted, their sacrifices denied. They were even accused of treason (Speech On the Occasion of Jordan's Independence Day, 24-May-07).

The topicality of 'the Hashemite sacrifices' in KAII's discourse reflects a significant aspect of the Hashemites' ideological beliefs. The King maintains that his ancestors' self-identity has been subject for de-emphasising. While the connotation of the word 'sacrifice' appeals to sympathy, KAII here positions the Hashemites into the 'victim' place to reflect an embedded aspect of the Hashemites' identity-description that shows their fine attributes; especially self-denial and altruism. In the jargon of the Hashemites, this sacrifice is mostly highlighted in Islamic history through the massacres of the Hashemites by the Umayyad caliphs in the first Hijri century, and which is commemorated by the martyrdom of Husayn ibn Ali, the grandson of the Prophet Muhammad at the Battle of Karbala in 61 After Hijra (around 680 CE) (See Encyclopædia Britannica Online: 'Battle of Karbala'). In modern history, for instances, the Hashemites' historical sacrifice was re-materialised by the assassination of King Abdullah I on the thresholds of Al-Aqsa Mosque in 1951 while attending Friday prayers in the company of his grandson, Prince (later King) Hussein.

One of the implications of the 'sacrifices' topic is that it aligns the Hashemite self-identity to that of Jordan and Jordanians who, according to KAII, have constantly sacrificed. Several times Jordanians have welcomed and offered refuge to thousands of displaced Arabs and Muslims, such as, Circassians, Palestinians, and Iraqi, who have been afflicted by conflicts and economic hardships in their homelands (See Schirin, 1994: 75). In return, KAII emphasises that as part of the properties of the Hashemites' description-identity involves 
unexpected sound disposition, the Hashemites, as it's expected of them, will remain adherent to their historical 'duties' which they have been entrusted:

5. ... [t]his has been the Hashemite approach since the dawn of history: We keep our doors wide open to the common good and the needy, and we will continue as such as long as God Almighty wills it for us. (A Letter to Nasser Lozi, 04-Oct-08)

The King's refers in extract 5 above to the Hashemites' self-identity description in terms of what they involves highlighting the Hashemites' sound values. What is more remarkable here is his use of the pronoun 'we' to emphasise how such disposition resembles that of Jordanians' original values which stem from their customs and traditions. This linguistic strategy of inclusion makes the proposition that the Jordanian Hashemites' self-identity is built on the disposition of creating a community where intrinsic Jordanian social relationships, especially tribe-hood, came to play a central role in the way in which Jordan, the state, is imagined (Layne, 1994:105). When these relationships between the Hashemite dominant ruling-class and the dominated Jordanians are respected, one can then infer that the in-group Hashemites' self-identity description in KAII's discourse associates the Hashemites' self-identity to that of the larger out-group original and genuine Jordanian (in addition to Arabic and Islamic) traits and norms but within the cloak of modernised norms of governance and domination.

\subsection{Modernity and Originality}

This repertoire materialises King Abdullah II's deliberate emphasis on 'Activity-descriptions' of the Hashemites' self-identity through their unparalleled deeds and achievements especially in adopting modern Western values and approaches to achieve progress in Jordan. Obtained first-class education in prestigious western academic and military institutions, KAII perceives Jordan, under his rule, is setting an example in development in science and technology, modernization, and democracy and freedom in order to be in evolutionary transition from an 'under-developed' (and 'traditional') country to a 'modern' one (King Abdullah II, 2012: 169-171). This 'modernity', as the King accentuates, shall ripen 'prosperity' and good fortune encompassed by comprehensive 'peace' in the region, the increase of the people's wealth, and the attainment of successful social status:

6. In fact, the Islamic Arab Hashemite heritage of the Prophet Mohammed that I am proud to belong to, advocates progress, prosperity and peace. (Speech at the World Economic Forum, 03-Feb-02)

7. ... that Jordan is a modern democratic country, [...], in order to promote Jordan as a civilised model for tolerance, freedom of thought, creativity and excellence. (Opening the First Ordinary Session of the 14th Parliament, 01-Dec-03)

In his discourse of modernity, both the Hashemites and Jordan are aligned to establish an 
in-group self-representation that 'advocates' the common activities which help making Jordan a 'prosperous' and 'peaceful' country under the Hashemites' reign and while maintain original Arabic and Islamic sound traditions. This is discursively attained through his constant call to the distinctiveness of the Hashemite governance in defending the values of reason, knowledge, education, and humanitarian values; these values the 'modern civilised' world are understood to be ignored by other rulers in the Arab world under the cover of traditions and customs. For instance, 'peace' is among these modern and original values repeatedly mentioned in KAII's discourse.

As he contemplates the individual's satisfaction is reflected through the prosperity of the group he/she belongs to, KAII regards 'peace' as what the Hashemites have always strived for. Setting an example of the considerate and wise rulers, the Hashemites, as KAII, says are the ones who promoted peace in an area that is always characterised by conflicts, intolerance, oppression, and degradation:

8. Jordan believes in a just and lasting peace and is conscious of its humanitarian role based on its Islamic, Arab, and Hashemite heritage. (A Letter to Prime Minister Ali Abul Ragheb, 25-Oct-01)

The Hashemites' adoption of a humanitarian and moderate perspective towards just peace in the region characterise the Hashemites' activity description as materialised through their renowned policies of implementing justice, freedom, and respect as they have called for in their Great Arab Revolt against the Ottomans at the verge of the $19^{\text {th }}$ century. These policies, as KAII once asserted, stem from the Arabic and Islamic heritage, and they are also adorned with the sound western movements of freedom and justice; epically the French Revolution:

9. The principles of justice, freedom and respect of human rights are the same ones for which my Hashemite grand-parents launched the Great Arab Revolt. They were inspired by the values of the French Revolution. ... (Speech at the Dinner Hosted by His Excellency the President of France Jacques Chirac, 15-Nov-99)

Here, the King foregrounds the interrelationship between the Great Arab Revolt which his grandparents launched and the French Revolution which is considered by historians as one of the most important events in human history. As the French Revolution marks the 'dawn of the modern era' (Frey and Frey, 2004: xiii), KAII analogically highlights that the Great Arab Revolt is marking the 'Dawn of the Modern Arabic Renaissance'. Thus, the Hashemites' self-identity is highlighted here by the activity-description in which they match themselves to the French who called for the sound values of 'justice', 'freedom' and respect of 'human rights' to societies who have been deprived from for ages. In this regard, the Hashemites activities description, according to KAII, have constructed another self-identity representation by which the Hashemites regards themselves the bridge of implementing equal partnership between the Arab world and western civilisation on the basis of equality; eliminating all the barrier of mutual misunderstanding, and misrepresentation, of the $u s$ by 
the other.

10. The great mutual admiration that has always characterised the relations between the Hashemite family and the leaders of the French Republic has been truly reflected in the course of relations between Jordan and France. (Speech On the Occasion of the Inauguration of King Hussein Street in Paris, 16-Nov-99)

Here, the mutual admiration and respect between Jordanians and French people emphasises the role that the Hashemites ruling-class in Jordan plays to bridge the gap between the East and the West. This also headlines how the Hashemites' recognise of the norms and values of mutual respect and friendship with 'democratic' nations and regimes; underlining here the rich resources of international support which the Hashemites' legitimacy based on. These norms have been sought to be transported to Jordan by means of 'reformative principles' to mark Jordan's transition towards modernisation and development under the Hashemites; who regard themselves as well as the 'vanguards of reform'.

\subsection{The Vanguard of Reform}

Upon assuming his duties, the King has called for radical change and improvement in the Jordanian state and its administrations. However, significant reform has not been noticed until the launch of the first waves of the 'Arab Spring' in 2011. When the public demands for reform in Jordan has intensified by the contagious optimistic spirit of the Spring, KAII responded that what his people demand coincides with his own vision of comprehensive reform which stems from the actual demands and needs of Jordanians, not as dictated by others:

11. We are keen to produce outcomes that enhance the distinguished performance of our political system to assert that our country is founded on a Hashemite heritage that has deep roots as the vanguard of constitutional reform. (A Letter to Mr. Ahmad Lozi, 26-Apr-11)

The King sees that the Hashemites' disposition has been always in favour of implementing reform; not only as response to the people's demands, but because they believe in. The Hashemites distinctively identify themselves as 'reformists', and KAII re-identifies himself as the 'vanguard' for reform. KAII's appeal to the heritage of his Hashemite ancestors in 'reform' establishes a remarkable aspect of the Hashemites' in-group self-representation. The 'vanguard of reform' rhetoric makes one of the most salient contemporary topics that establish the Hashemites' legitimacy (See Lynch, 2005). For instance, the increasing public demand to 'fight' corruption in the state foregrounds the King's position as leading the 'path' towards reform and the 'battle' against the people, and the state's, main 'enemy': corruption. Here, the topicality of 'reform' in KAII's discourse necessitates the reliance on self-confident language in which the King accentuates his possession of the most vital and necessary means to achieve his reformative goals. Being a member of the powerful dominant group, he has the 
constitutional authority to reform and repair all that is wrong, corrupt, and unsatisfactory in the state and its administrations. Nevertheless, KAII sees what he wants is achieving a gradual, but solid, reform through the constitutional institutions:

12. The recommendations concerning provisions of our Constitution that have been presented here today to me is... solid proof of Jordan's ability to revitalise itself and its legislation and approach the future with a vision of social and political reform, the foundation of which is wider public participation, the separation between the branches of government and a clear definition of the responsibilities of each of these branches in a manner that truly reflects the Hashemite tradition and good governance in state administration. (Remarks On the occasion of presenting the suggested constitutional amendments by the Royal Committee on Constitutional Review, 14 August 2011)

The King's assertive language in extract 12 above is based on logical argument with detailed accounts. However, this language can be also understood as a protective measure by which KAII absorbs his people's dissatisfaction resulted from continuous recent deterioration of life conditions in Jordan.

Achieving reform gradually through the constitutional institutions is perceived by KAII as evidence of the Hashemites objective perspective towards authority and power. The Hashemites repeatedly portray themselves as 'servants' to their subjects, and KAII regards his 'duties' involve listening to his peoples' wants in the one hand and respecting the existing political and constitutional institutions on the other. To maintain an even-handed approach, KAII accentuates that reform should be 'comprehensive' and well-established because it stems from a strong feeling of responsibility and moral obligation from his part to listen to the demands of his people. Still, he de-emphasises his, or the Hashemites', role because he believes that it is the responsibility of Parliament and national political parties to formally implement reform and make it real.

\section{Discussion and Conclusion}

This article illustrates the case of employing three socio-cultural representations within a set of 'repertoires' which all encapsulate different layers of the Hashemites' self-identity in KAII's discourse. As Fairclough states that all texts: ' ...express the social identities of their producers and address the assumed social identities of their addressees and audiences.' (Fairclough, 1995: 123), the discourse we examined represents KAII's attempt to achieve hortatory goal by which the Hashemite (monarchy) ruling-class establishes its legitimacy in Jordan. In this attempt, the three socio-cultural representations presented characterise our understanding of the social relations, and the implicit ideologies by which the Hashemites have obtained and maintained dominance over Jordanian people.

My choice of the discourse of the Hashemites, in which they establish their self-identity, is motivated by van Dijk's argument that 'social power is based on privileged access to socially 
valued resources, such as wealth, income, position, status, force, group membership, education or knowledge.' (van Dijk. 1993: 254). The discourse of the Hashemites' represents that of the Jordanian power elites (Domhoff, 1978), and for centuries, the Hashemites' rulers have commanded the most attention of Arabic discourse by virtue of their privileged authority and power, and their views are recognised the most influential in the hegemonic construction of the mainstream of both the Hashemites' self-identity and the Jordanians' national one. What is more, as the Hashemites in Jordan enjoy tremendous social power, they evidently have greater access to the tools of persuasion (e.g. the media, political office). Accordingly, the dominant Hashemite ruling-class can easily use strategies to 'change the mind of others in one's own interests' (van Dijk, 1993: 254).

The result, in line with the theoretical assumptions of Critical Discourse Analysis regarding the notions of self-identity and ideology, emphasises the conjecture that 'ideology invests language'. KAII has invested language to construct an ideology that maintains the Jordanian people, Arabs, and Westerners' positive stance to the Hashemites and their regime in Jordan. The stance of the dominated Jordanian is expected to be generated - to a great extent - from the linguistic behaviour of their dominants. This, in turn, has remarkably raised an awareness of a national identity by which Jordanian people affiliate themselves, and evaluate others, in respect of the 'privileged' (from their viewpoint) status of being subject to the Hashemite rulers. Such an account covers the dimensions of the Hashemite self-identity as it directs a generalization and conventional conception that regards Jordan as a 'the Hashemite Jordan'. This conception is plainly represented and perceived in school history textbooks, governmental discourse, and state's media. As Herman and Chomsky (1988) demonstrated, one of the major functions of dominant discourse (that is, the discourse of dominant groups) is to manufacture consensus about and acceptance of their dominance. The Hashemite ruling-class 'categorizes and builds', 'imposes' and 'exercises' (See Fairclough, 1999: 168) its self-identity by manipulating power relations; especially those of the ' $u s$ ' and 'them'.

The conventional dichotomy of the 'us' and 'them' as the Hashemites perceive is based on the fact that people tend to identify the group they are, or become, members of (Phillips and Jørgensen, 2002: 100pp). We see that KAII identifies himself to the Hashemites according to 'how special He is' to be able to maintain Jordan a homogenous unified nation as his Hashemite ancestors did. He then constructs his, and the Hashemites', legitimacy through highlighting how different the Hashemites are when compared to other rulers (or regimes). The unifying language, which KAII then uses, reflects the ideological belief that a leader is expected to fit a well-established set of self-representations. This emphasises what Norman Fairclough accentuates:

'Leader identity in contemporary politics is built upon a tension between the public office and the private individual, the extraordinary position of leader and the ordinary person who holds it. In terms of language, this means a tension between the public language of politics and everyday life' (Fairclough, 2000: 97).

In KAII's discourse, the leader's self-identity is built within the Jordanian context by emphasising the exceptionality of the Hashemites. This exceptionality highlights the 
hypothesis that when compared to other regimes, the Hashemites have always excelled themselves in most domains of ruling experience both on what they are and what they do. KAII accentuates that the Hashemites have remarkably surpassed the average norms when compared to other rulers first as descendant of the Prophet, and second when they adopted modernity and western humanitarian values of democracy, and third in his own stance to implement reform in Jordan. This stance manifests through KAII's excessive reliance on emotional jargon which reflects the Hashemites' invariable self-esteem to their role in shaping Arabic, and Jordanian, history and culture. The outcome is that the exceptionality of the Hashemites by birth, deeds, and visions dictates the exceptionality of Jordan as a state under the Hashemites' rule:

13. Jordanians and people from around [....] would cherish the memory of a selfless leader [Late King Hussein], who sacrificed for the sake of ensuring that his country, his people and his region will have a better life than the one he had. A Hashemite by birth and a Hashemite by deeds, King Hussein's achievements will outlive us all. (Speech On the Occasion of the Inauguration of King Hussein Street in Paris, 17-Nov-99)

This collective in-group self-representation is materialised through the King's, and Jordanian public media, discourse which chant how Jordan has become the 'model' and the 'example':

14. So that Jordan's roots continue to be firmly established and resolute in its own surroundings and throughout the world, for Jordan, with its Hashemite mandate, is Jordan the pioneer, Jordan the model and the example to be followed.(Opening the First Ordinary Session of the $14^{\text {th }}$ Parliament, 01-Dec-03)

Within this same position, KAII refers to the will of God by which he, and his ancestors, have been 'entrusted' to fulfil what is best for Jordan and the Arabs under the Hashemites' governance:

15. May God keep Jordan a proud and free country and an Arab Hashemite haven and may He grant you and your colleagues success as you carry out this noble mission. (A letter To Mr. Ahmad Lozi, 26-Apr-11)

Herein, KAII emphasises the high prominent position of the 'Hashemite Jordan' as a peaceful and safe place to live in; marginalising the status of other neighbouring countries which do not enjoy what God have blessed Jordan with.

To sum up, the main objective of the article was not to subjectively re-assert the 'exceptionality' of the Hashemites and their regime; but rather to engage in the growing literature in critical discourse analysis by which we reveal how language shapes the personal 
and collective identity of a dominant ruling-class. And we identified how the socio-cultural representations of historical legacy and religious affiliation, modernity and originality, and the vanguard of reform emerge in KAII's discourse within a socio-political context to achieve a hortatory purpose that stands for three integrated layers of the Hashemites self-identity.

From pure historical account, the recurrent reference to the conception of the 'Hashemite Jordan' in KAII's discourse aimed to exemplify the era of KAII's reign. The historical and political situation in Jordan (especially since 2003) has been soaring by many international challenges; such as the launch of the second intifada in the West Bank and the invasion of Iraq, and the challenge of economic reform, and the Arab Spring. All these, among many other challenges, have forced the King to reintroduce a discourse that works on re-building the Jordanian's priorities and expectations. Commercialising the conception 'Hashemite Jordan' and reinforcing the exceptionality of Jordan under the Hashemites have helped the monarchy, and the regime, to build their legitimacy under the topic of the exceptionality of the relationship between the 'Hashemites' and 'Jordan'. This relationship is represented as the model that defines the relationship between the dominant and the dominated. This definition, in fact, helped the successive Jordanian governments to launch several 'de-liberalized' efforts to contain any potential kind of opposition posed by exterior and domestic unrest. Since history tells that contemporary Jordan has not known other rulers than the Hashemites, the establishment of a distinctive 'Hashemite Jordan' worked on uniting people under the flag of the Hashemites. This has established a substitute to the core of discussions on the exact priorities of Jordanian people on relevance to their individual identities to serve the interests of a unified collective Hashemite identity.

\section{References}

Abu-Rish, Z. (2011). Five Questions on Jordan. Jadaliyya Blog. February 12. In 'the People of Jordan Want': A Conceptual Analysis of the March 24 Reform Movement in Jordan. (Interview with Rafiq, a political activist in Amman November 28, 2011) By Mai Hoff Skovgaard AU, International Studies, March 1, 2012. [Online] Available: http://www.jadaliyya.com/pages/index/625/five-questions-on-jordan

Bamberg, M., De Fina, A., \& Schiffrin, D. (2011). Discourse and Identity Construction. In S. J. Schwartz, K. Luyckx, \& V. L. Vignoles, V. L. (Eds.), Handbook of Identity Theory and Research. Berlin: Springer Verlag. 177-199.

"Battle of Karbala". Encyclopadia Britannica Online, Accessed on 10 July 2013 via http://www.britannica.com/EBchecked/topic/312214/Battle-of-Karbala.

Chevallier, D. (2003). Orient D’encre: Entre Guerre Et Pouvoir. Paris: Actes Sud.

Davies, B., \& Harré, R. (1990). Positioning: The discursive production of selves. Journal of the Theory of Social Behaviour, 20(1), 44-63. http://dx.doi.org/10.1111/j.1468-5914.1990.tb00174.x

De Cillia, Rudolf, Reisigl, Martin, \& Wodak, Ruth. (1999). The Discursive Construction of National Identities. $\quad$ Discourse Society, 10, 149-173. 
http://dx.doi.org/10.1177/0957926599010002002

Domhoff, G.W. (1978). The Powers That Be: Processes of Ruling Class Domination in America. New York: Random House.

Fairclough, N. (1989). Language and power. London: Longman.

Fairclough, N. (1992). Discourse and Social Change. Cambridge: Polity Press.

Fairclough, N. (1995). Critical Discourse Analysis. London: Longman.

Fairclough, N. (2000). New Labour, New Language? London: Routledge

Farr, R. M., \& Moscovici, S. (Eds) (1984). Social Representations. Cambridge: Cambridge University Press.

Foucault, M. (1972). The Archeology of Knowledge. New York: Pantheon.

Frey, L., \& Frey, M. (2004). The French Revolution. Westport, Connecticut: Greenwood Press.

Frisch, H. (2002). Fuzzy Nationalism: The Case of Jordan. Nationalism and Ethnic Politics, 8- 4. 2, 86-103.

Geison, G. L. (Ed.). (1983). Professions and professional ideologies in America. Chapel Hill: University of North Carolina Press.

Goffman, Erving. (1959). The presentation of self in everyday life. New York: Doubleday.

Herman, E. S., \& Chomsky, N. (1988). Manufacturing Consent: The Political Economy of the Mass Media. New York: Pantheon Books.

King Abdullah II. (2012). Our Last Best Chance: A Story of War and Peace. London: Penguin Books.

Lawrence, T. E. (1926). Seven Pillars of Wisdom. London: Penguin Classics.

Layne, L. (1994). Home and Homeland: The Dialogics of Tribal and National Identities in Jordan. Princeton: Princeton University Press.

LePage, R. B., \& Tabouret-Keller, A. (1985). Acts of Identity: Creole Based Approaches to Language And Ethnicity. Cambridge, UK: Cambridge University Press.

Lucas, R. (2008). Side Effects of Regime Building in Jordan: The State and the Nation. Civil Wars, 10(3), 281-293. http://dx.doi.org/10.1080/13698240802168098

Lynch, M. (2005). Jordan: Knives Out for the National Agenda. Arab Reform Bulletin, 3(9). [Online] Available: http://carnegieendowment.org/2008/08/20/knives-out-for-jordan-s-national-agenda/fhza Massad, J. (2001). Colonial Effects: The Making of National Identity in Jordan. New York: Columbia University Press. 
Pennycook, A. (2010). Language as a Local Practice. London: Routledge.

Phillips, L., \& Jørgensen, M. (2002). Discourse Analysis as Theory and Method. Cornwall: TJ International Ltd.

Salibi, K. S. (2006). The Modern History of Jordan. New York: I.B. Tauris.

Schirin F. (1994). Jordan: An Invented Nation? Tribe-State Dynamics and the Formation of National Identity. Hamburg: Deutsches Orient Institute.

Teitelbaum J. (1998). Sharif Husayn ibn Ali and the Hashemite Vision of the Post-Ottoman Order: From Chieftaincy to Suzerainty. Middle Eastern Studies, 34(1), 103-122.

van Dijk, T. (1993). Principles of Critical Discourse Analysis. Discourse \& Society, 4, 249-83.

van Dijk, T. (2001). Critical Discourse Analysis. In Schiffrin, D. et al. (Eds.), The Handbook of Discourse Analysis. London: Blackwell, pp. 352-371.

van Dijk, T. (2003). Political Discourse and Ideology. DOXA COMUNICACIÓN $N^{o} 1$. [Online] Available: http://www.doxacomunicacion.es/es/hemeroteca/articulos?id=124

van Dijk, T. (unknown). Ideological Discourse Analysis. [Online] Available: www.discourses.org/OldArticles/Ideological\%20discourse\%20analysis.pdf

Wodak, R. et. al. (1999). The Discursive Construction of National Identity. (Trans. A. Hirsch and R. Mitten). Edinburgh: Edinburgh University Press.

\section{Note}

Note 1. http://dx.doi.org/10.1017/CBO9781139524742.015 